\title{
Teksten som problem i lingvistik, filologi og andre humanistiske videnskaber
}

Forsøg på en filosofisk analyse

\section{Oversatternes forord}

Den russiske sprog-og litteraturforsker Mikhail M.Bakhtin (18951975) blev kendt $i$ det danske forskningsmiljø ved en nasten samtidig introduktion gennem Peter Madsen og Anker Gemzфes arbejder om ham.' Bakhtin er siden blevet brugt flittigt, isar af litterater, men hans arbejder har i oversattelse kun varet tilgangelige på engelsk, tysk, fransk og senest svensk; han er aldrig blevet oversat til dansk.

Artiklen »Teksten som problem« er et af Bakhtins sene arbejder, oprindeligt nogle af hans eksperimentelle notater fra 1959-61; men de blev forst publiceret $i$ 1976, efter hans d $\emptyset$, i tidsskriftet Voprosy Literatury og så igen tre år senere, efter nogen redigering, $i$ bogen Estetika Slovesnogo Tvortjestva, forsynet med udforlige noter. Det er denne senere udgave, ${ }^{2}$ vi har valgt at oversatte her.

"Teksten som problem « er den første »danske« Bakhtin på tryk, og det er med velberäd hu, at vi har valgt netop dette sene vark. Her blotlagges den organiske sammenhang mellem de hovedtemaer, der interesserede Bakhtin gennem ärtier og som tenderede mod en syntese af filologi og filosofi. Bakhtin prasenterer disse temaer som en sarlig og ny humanistisk disciplin, dannet i granseområdet mellem lingvistik, filosofisk antropologi og litteraturvidenskab. Ud over at definere og uddybe sit forskningsområde samler Bakhtin $i$ denne artikel sine hidtidige ideer omkring det dialogiske ord ${ }^{3}$ og forbinder dette begreb med begrebet tekst. Denne sidste term behandles også af Bakhtin i den udvidede og bearbejdede udgave af bogen Problemy Poetiki Dostojevskogo. ${ }^{4}$ Alt dette gør "Teksten som problem « til et meget vigtigt vark for forstäelsen af hele Bakhtin. 
Som lasere af Bakhtin på hans modersmål har vi folt et stigende behov for en oversattelse til dansk som skulle ligge tcet på originalen ud fra den betragtning, at der i hidtidige oversattelser til engelsk, tysk og fransk ligger for megen tolkning af vigtige begreber, ligesom vi har fundet en del fejl. Således har vi $i$ Vern W.McGees engelske oversattelse, redigeret af Caryl Emerson og Michael Holquist ${ }^{5}$ og almindelig anerkendt som den bedste »engelske Bakhtin, fundet en del fejl. Eksempelvis er »bessubjektno« (»subjectless") oversat som »objectless" if flgende: "Can one say that the comprehension of a language as a system is objectless and completely devoid of dialogic aspects? « (p. 111). "Det er imidlertid kun den der forstär, dvs. subjektet, der kan g $\phi$ re forståelsesprocessen dialogisk. Forståelsens objekt er jo altid til stede, for det er sproget selv, hvilket gфr hele den engelske formulering af sporgsmålet meningslos. Den hyppigst forekommende fordrejning af Bakhtin sker, når overscotteren prover at polere den bakhtinske tanke. »Initially, belief required only understanding - interpretation. This belief was brought to bear on profane texts (the study of language and so forth) « (p. 103). Dette er, strengt taget, ikke en oversattelse, men oversatterens »tolkning "af folgende to satninger: "Initially - belief, that requires understanding - interpretation. Application of profane texts (language teaching and so on). "Det er hvad Bakhtin har skrevet, men selvfфlgelig er det umuligt at lase videre uden at bestemme sig for. hvordan man vil forstå disse linjer. Bakhtin tvinger laseren til at reflektere over sine egne ord, han inddrager laseren i en dialog med sig selv, og det er netop dette, der er formàlet med hans »ufardige« måde at skrive på. "Fardiggфrelsen« er derfor den groveste fejl en oversatter kan begå mod den bakhtinske originaltekst. Bakhtins "ufardige« fremstillingsform her er ikke et hjalpel $\phi$ st rod af forvirrede tanker, men tvartimod resultatet af den dannede litterat, den erfarne skribent og sprogvidenskabsmands mangearige straben mod pracision. Det er måske ikke en stilistisk helstobt, fardig tekst, det er med Bakhtins egne ord "eksperimentelle notater. Men man kan ikke betvivle Bakhtins beherskelse af sit modersmål eller hans evne til at udtrykke nojagtigt det,

\footnotetext{
А. Mожно ли Говорить, что попимание языка как

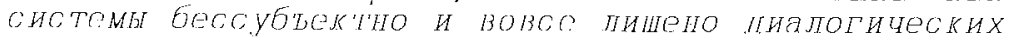
MOMOHTOB.
}

- Heрвонатальио вера, требутщая 'олько понимания истолкования. ОБрашоние $k$ профанным текотам (oбучение языкам и т. л.). 
han vil. Med den tilsyneladende »ufardighed « $i$ de sene artikler laver Bakhtin et dristigt eksperiment i at leve op til sin egen dialog-teori og leverer den på en udpraget dialogisk, subjekt-kravende og hermed "laseruvenlig måde.

Mere pracist omfatter vores betegnelse »ufardig « følgende vasentlige sproglige karakteristika: Bakhtins ordvalg kan til tider virke provokerende inkonsekvent eller tvetydigt, idet han bruger forskellige gloser om fanomener, som i fagligt sprog bor vare terminologiseret, dvs. precist defineret og standardiseret: ikke-lingvistisk/metalingvistisk, ${ }^{6}$ forfatter/autor, mening/betydning etc. Han overskrider tit fagsprogets stilistiske granser og inddrager gloser med kirkeslavisk klang, som det er svart at gengive på andre sprog; han organiserer kohasionen på en sådan måde at koharens ikke bliver entydig; han bruger meget tit parentes, tankestreg, kursiv, og han bruger dem med vidt forskelligt formål (til at konkretisere, generalisere, uddybe, aftede, omformulere, udvikle, gentage sin tanke osv.) - »og så videre« er i øv rigt et af Bakhtins yndlingsudtryk, som han bruger for at undgà at satte et definitivt punktum. Forlobet $i$ hans tankegang er mangerettet og ikke ensrettet; emnerne følger ikke hinanden i pan rakkefølge, men koges sammen. Bakhtin cirkler rundt og kommer tilbage til forladte emner, så der gradvist, under forudsatning af laserens aktive samarbejde (dialog), skabes et helhedsbillede af hans polyfone vision, uden at der dog opnås noget så kunstigt og for han forkasteligt som et »slutresultat«, et endegyldigt svar.

NB: 1995 er 100-året for Mikhail M.Bakhtins fødsel.

Nina Møller Andersen Svetlana Klimenko 
Vores analyse må kaldes filosofisk først og fremmest på grund af overvejelser af negativ karakter: det er hverken en lingvistisk, en filologisk, en litteraturvidenskabelig eller nogen anden speciel analyse (unders $\emptyset$ gelse). Derimod er de positive overvejelser følgende: vores undersøgelse bevæger sig i grænseområderne, skellene og krydsningerne mellem alle de ovenfor næunte discipliner.

Teksten (skriftlig og mundtlig) er det oprindeligt givne i alle disse discipliner og i det hele taget i den humanistisk-filologiske tænkning (herunder også i den oprindelige teologiske og filosofiske tænkning). Teksten er den umiddelbare virkelighed (tankens og oplevelsens virkelighed). Det er kun derfra, at disse discipliner og denne tænkning kan udgå. Hvor der ikke er tekst, er der heller ikke noget objekt for forskning eller tænkning.

'Underforstået' tekst. Hvis man vil forstå teksten bredt - som ethvert sammenhængende tegnkompleks - så har også kunstvidenskaben (musikvidenskab, de bildende kunsters teori og historie) noget at gøre med tekster (kunstværker). Tanker om tanker, oplevelser af oplevelser, ord om ord, tekster om tekster. I dette ligger hovedforskellen mellem vores (de humanistiske) discipliner og de naturvidenskabelige, selv om der heller ikke engang her er nogen absolutte, uoverskridelige grænser. Den humanistiske tanke opstår som tanke om andres tanker, andres viljesytringer, manifestationer, ytringer, tegn, i hvilke guder (åbenbaringer) eller mennesker (herskernes love, forfædrenes bud, anonyme sentenser, gåder osv.) giver sig til kende. Den videnskabelige cksakte »pastvang « for tekster og tekstkritikken selv er senere fænomener, hvis man kan sige det sådan, (der er en hel omvæltning af den humanistiske tæenkning, mistillidens opståen). Først troen, som kun kræver forståelse -fortolkning. Brug af profane tekster (sprogindlæring osv.). Det er ikke vores hensigt at fordybe os i de humanistiske videnskabers historie generelt eller i filologiens og lingvistikkens historie - vi er interesserede i det specifikke ved den humanistiske tanke, dens indretning på andres tanker, meninger, betydninger osv., som er manifesteret og foreligger for forskeren alene i form af en tekst. Lige meget hvad der er undersøgelsens endemål, kan udgangspunktet kun være en tekst.

Vi vil kun beskæftige os med de verbale tekster, som er det oprindeligt givne i de pågældende humanistiske discipliner - i første række lingvistik, filologi, litteraturvidenskab m.v.

Enhver tekst har et subjekt, en autor (talende eller skrivende). Forfatteridentitetens mulige typer, arter og former. Den lingvistiske analyse kan i det hele taget inden for visse rammer helt abstrahere fra forfatteridentiteten. Fortolkning af teksten som eksempel (f.eks. propositioner, syllogismer i logikken, sætninger i grammatikken, 'kommutationer' i lingvistikken osv.). Imaginære 
tekster (som eksempler og andre typer). Konstruerede tekster (til et lingvistisk eller stilistisk eksperiment). Overalt opstår der særlige forfattertyper, der udtænker eksempler og eksperimenterer med deres særlige form for forfatteransvarlighed (her er også et andet subjekt: den, der kunne sige sådan).

Problemet tekstens grænser. Teksten som ytring. Problemet tekstfunktioner og tekstgenrer.

To momenter, som bestemmer teksten som ytring: dens idé (intention) og realiseringen af denne idé. De dynamiske vekselvirkningsforhold mellem disse momenter, deres kamp - som bestemmer tekstens karakter. Deres divergens kan være meget sigende. »Sidt « hos L.Tolstoj. ${ }^{7}$ Fortalelser og skrivefejl ifølge Freud (udtryk for det ubevidste). Ændringen af ideen i realiseringsprocessen. Ikke-opfyldelsen af den fonetiske hensigt.

Problemet det andet subjekt, som reproducerer (med det ene eller det andet formål, herunder forskningen) en tekst (den andens) og som skaber en rammetekst (kommenterende, vurderende, modsigende osv.).

Et særkende for den humanistiske tankegang er, at der er to planer og to subjekter. Tekstologi som teori og praksis i den videnskabelige reproduktion af litterære tekster. Det tekstologiske subjekt (tekstologen) og dets særegenheder.

Problemet iagttagerens synsvinkel (rum- og tidsmæssigt udgangspunkt) inden for astronomi og fysik.

Tekst som ytring, der er inkluderet i talesamvær (tekstkæde) i en given sfære. Teksten som en særlig monade, som genspejler alle tekster (inden for rammerne) af en given meningssfære. Den gensidige forbindelse af alle meninger (for så vidt de realiseres i ytringer).

De dialogiske forhold mellem tekster og inden for tcksten. Deres særlige (ikke-lingvistiske) karakter. Dialog og dialektik.

Tekstens to poler. Enhver tekst forudsatter et almindeligt anerkendt (dvs. konventionelt inden for et givet kollektiv) tegnsystem, sprog (selv kunstens sprog). Hvis der ikke står et sprog bag teksten, så er det ikke nogen tekst, men et ægte naturfænomen (ikke tegnfænomen), for eksempel et kompleks af naturlige skrig og støn, som ikke har sprogets (tegnets) repeterbarhed. Selvfølgelig inkluderer enhver tekst (både mundtlig og skriftlig) en betydelig mængde af forskelligartede, ægte, naturlige momenter, der ikke er tegn, og som går ud over den humanistiske forsknings grænser (lingvistisk, filologisk og andre), men der tages også hensyn til dem (beskadigelse af manuskriptet, dårlig diktion osv.). Rene tekster findes ikke. Desuden er der i enhver tekst en række aspekter, som kan kaldes tekniske (den tekniske side af grafik, udtale og lignende).

Det vil sige, bag enhver tekst står et sprogsystem. I teksten svarer alt genta- 
get og reproduceret, gentageligt og reproducerbart, alt som kan forekomme uden for den givne tekst, til dette sprogsystem. Men samtidig er enhver tekst (som ytring) noget individuelt, unikt og uigentageligt, og i dette ligger hele dens idé (det formål, hvortil den er skabt). Det er det i den som har med ærlighed, sandhed, godhed, skønhed, historie at gøre. I forhold til dette aspekt er alt det gentagelige og reproducerbare materiale og middel. Dette găr til en vis grad ud over lingvistikkens og filologiens grænser. Dette andet aspekt (denne anden pol) er karakteristisk for selve teksten, men viser sig kun i situationen og tekstkæden (i talesamvær inden for en given sfære). Denne pol er ikke forbundet med sprogsystemets (gentagelige) elementer (tegn), men med andre (uigentagelige) tekster via særlige dialogiske (og, ved abstraheren fra forfatteren, dialektiske) relationer.

Denne anden pol er uløseligt forbundet med forfatteridentiteten og har intet til fælles med det ægte og naturlige enkelttilfælde; den realiseres helt og holdent ved hjælp af sprogets tegnsystem. Den realiseres af ren kontekst, skønt den gror til med naturlige momenter. Alle grænser er relative (for eksempel, hvor skal man placere en oplæsers stemmes klangfarve osv.). Andring af funktioner bestemmer også ændring af grænser. Forskel mellem fonologi og fonetik.

Problemet det meningsmæssige (dialektiske) og dialogiske forhold mellem tekster inden for grænserne af en bestemt sfære. Det særlige problem teksternes historiske vekselvirkningsforhold. Alt dette i lyset af den anden pol. Problemet den kausale forklarings grænser. Det er vigtigt ikke at rive sig løs fra teksten (selv den mulige, den tænkte, den konstruerede).

Åndsvidenskab. Ånd (både ens egen og den fremmedes) kan ikke gives som ting (de naturlige videnskabers direkte objekt), men kun som tegnudtryk, realiseret i tekster både for sig selv og for den anden. Kritik af selviagttagelse. Men det er nødvendigt med en rig, dyb og fintfølende forståelse af teksten. Tekstteori.

Naturlig gestus i skuespillernes spil făr tegnbetydning (som vilkårlig, spillet, underordnet rollens idé).

Et naturligt enestående tilfælde (for eksempel et fingeraftryk) og tekstens meningsfyldte (signifikante) uigentagelighed. Kun den mekaniske reproduktion af fingeraftryk er mulig (i hvilket som helst antal eksemplarer); den mekaniske reproduktion af en tekst er selvfølgelig også mulig (for eksempel kopiering), men en tekstreproduktion af et subjekt (tilbagevenden til den, gentaget læsning, ny udførelse, citater) er en ny, uigentagelig begivenhed i tekstens liv, et nyt led $\mathbf{i}$ den historiske kæde af talesamvær.

Ethvert tegnsystem (dvs. ethvert sprog), lige meget hvilket snævert kollektiv det støtter sin betingethed på, kan principielt altid dechifreres, dvs. oversæt- 
tes til andre tegnsystemer (andre sprog); følgelig er der en fælles logik i tegnsystemer, et potentielt fælles sprogenes sprog (som selvfølgelig aldrig kan blive et konkret sprog, et ud af mange sprog). Men teksten (til forskel fra sproget som system af midler) kan aldrig oversættes fuldstændigt, fordi der ikke findes en potentiel teksternes tekst.

Tekstens liv som begivenhed, dvs. dens sande væsen, udvikler sig altid $p a$ overgangen mellem to bevidstheder, to subjekter.

Den humanistiske tænknings stenogram er altid stenogram af en særlig type dialog: det indviklede vekselvirkningsforhold mellem teksten (objekt for udforskning og overvejelser) og den skabte, indrammende kontekst (spørgende, modsigende osv.), hvori videnskabsmandens erkendende og vurderende tanke realiserer sig. Dette er et møde mellem to tekster - den færdige og den som skabes som reaktion på den, og cr altså et møde mellem to subjekter, to forfattere.

Teksten er ikke en ting, og derfor kan man på ingen måde eliminere eller neutralisere den anden bevidsthed, modtagerens bevidsthed.

Det er muligt at gå til den første pol, det vil sige til sproget - forfatterens sprog, genrens, retningens, epokens sprog, det nationale sprog (lingvistik) og endelig til sprogenes sprog (strukturalisme, glossematik). Det er muligt at bevæge sig til den anden pol, til teksten som uigentagelig begivenhed.

Mellem disse to poler ligger alle mulige humanistiske discipliner, som udgår fra teksten som oprindelig begivenhed.

Begge poler er ubetingede: ubetinget er det potentielle sprogenes sprog og ubetinget er den eneste og uigentagelige tekst.

Enhver agte, skabt tekst er altid personlighedens åbenbaring, som til en vis grad er fri og ikke forudbestemt af empirisk nødvendighed. Derfor tillader den (i sin frie kerne) hverken kausal forklaring eller videnskabelig forudsigelighed. Men dette udelukker selvfølgelig ikke en indre nødvendighed, en indre logik i tekstens frie kerne (uden hvilken den hverken kunne forstås, anerkendes eller have virkning).

Teksten som problem i de humanistiske videnskaber. Humanistiske videnskaber er videnskaber om mennesket i sin specificitet og ikke om et naturfænomen eller en ting uden stemme. Mennesket i sin specificitet udtrykker sig altid (taler), dvs. skaber en tekst (selv en potentiel). Der, hvor mennesket bliver studeret uden for teksten og uafhængigt af denne, er der ikke længere humanistiske videnskaber (menneskets anatomi, fysiologi osv.).

Teksten som problem i tekstologien. Den filosofiske side af dette problem.

Forsøget på at studere teksten som 'verbal reaktion' (behaviorisme). ${ }^{8} \mathrm{Ky}$ bernetik, informationsteori, statistik og teksten som problem. Problemet tekstens tingsliggørelse. Grænserne for en sådan tingsliggørelse. 
Menneskets handling er en potentiel tekst og kan kun forstås (som menneskets handling og ikke fysisk handling) i sin egen tids dialogiske kontekst (som replik, som idéposition, som system af motiver).

»Alt det ophøjede og smukke « - dette er ikke en fraseologisk enhed i almindelig forstand, men en særlig slags ekspressiv eller intoneret ordsammensætning. Det er en repræsentant for stil, for verdensanskuelse, for en mennesketype, den dufter af kontekster, i den er der to stemmer, to subjekter (det som ville kunne sige sådan for alvor, og det som parodierer det første). Separat betragtet (uden for sammensætningen) er ordene »smuk « og »ophøjet « fri for tostemmighed; den anden stemme indgår kun i ordsammensætningen, som hermed bliver til ytring (dvs. den făr det talesubjekt, uden hvilket der ikke ville være den anden stemme heller). Også et enkelt ord kan blive tostemmigt, hvis det bliver en forkortelse af en ytring (dvs. fär en autor). Den fraseologiske enhed er skabt ikke af den første, men af den anden stemme.

Sprog og tale, sætning og ytring. Talesubjekt (generaliseret, 'naturlig' individualitet) og ytringens autor. Skift mellem talesubjekterne og skift mellem de talende (ytringens autorer). Sprog og tale kan identificeres med hinanden, eftersom ytringens dialogiske grænser er slettet i tale. Men sprog og talesamvær (som den dialogiske udveksling af ytringer) kan aldrig identificeres med hinanden. Absolut identitet mellem to eller flere sætninger er mulig (når man lægger dem oven på hinanden som to geometriske figurer, falder de helt sammen), desuden må vi antage, at enhver sætning, selv en kompleks, i en ubegrænset talestrøm kan gentages et ubegrænset antal gange i fuldstæendig identisk form, men som ytring (eller del af ytring) kan ikke en eneste sætning, selv en satning på et ord, nogensinde gentages: det er altid en ny ytring (selv et citat).

Spørgsmålet opstår: kan videnskab have noget med sådanne absolut uigentagelige individualiteter som ytringer at gøre; overskrider de ikke grænserne for en generaliserende videnskabs erkendelse. Selvfølgelig kan den det. For det første er udgangspunktet for enhver videnskab de uigentagelige tilfælde, og hele vejen forbliver videnskaben forbundet med dem. For det andet kan og skal videnskaben, og først og fremmest filosofien, studere denne individualitets specifikke form og funktion. Det er nødvendigt at være helt bevidst om en konstant korrigering af krav om fuldstændig udtømmelse ved hjælp af en abstrakt analyse (f.eks. lingvistisk) af en konkret ytring. Studiet af typer og former for dialogiske relationer mellem ytringerne og deres typologiske former (ytringens faktorer). Studiet af ikke-lingvistiske og samtidig ikke-indholdsmæssige (kunstneriske, videnskabelige osv.) momenter i ytringen. En hel sfære mellem den lingvistiske og den rent indholdsmæssige analyse; denne sfære er tabt for videnskaben.

Inden for grænserne af en og samme ytring kan en sætning gentages (gen- 
tagelse, selvcitat, ufrivilligt), men hver gang er det en ny del af ytringen, eftersom dens plads og funktion i hele ytringen ændres.

Ytringen som helhed er formet som sådan af ikke-lingvistiske (dialogiske) momenter, den er også forbundet med andre ytringer. Disse ikke-lingvistiske (dialogiske) momenter gennemtrænger også ytringen indefra.

Samtlige den talendes ytringer $i$ sproget (personlige pronominer, finitte verbalformer, grammatiske og leksikalske udtryksformer for modalitet og udtryk for den talendes holdning til sin egen tale) og talesubjektet. Ytringens autor.

Ud fra ytringens ikke-lingvistiske mål er alt det lingvistiske’ kun et middel.

Problemet autor og de måder han er udtrykt på i et værk. I hvor høj grad kan man tale om 'et billede' af autór?

Vi finder (opfatter, forstår, fornemmer, føler) autor i ethvert kunstværk. For eksempel, $i$ et maleri føler vi altid dets autor (kunstneren), men vi ser ham aldrig sådan, som vi ser det, han har skildret. Vi føler ham (det skildrende subjekt) som rent, skildrende princip og ikke som noget skildret (noget synligt). I et selvportræt ser vi selvfølgelig ikke den kunstner som har skildret det, vi ser kun kunstnerens skildring. Strengt sagt er forfatterbilledet contradictio in adjecto. Det såkaldte forfatterbillede er sandt nok et billede af en særlig type, som adskiller sig fra andre billeder i et værk, men det er alligevel et billede, og det har sin autor, ham der skabte det. Billedet af fortælleren i en jeg-fortælling, billedet af helten i selvbiografiske værker (selvbiografier, bekendelser, dagb $\varnothing$ ger, memoirer og andre), den selvbiografiske helt og lignende. De bliver alle målt og defineret ud fra deres forhold til forfatteren som menneske (som en særlig genstand for skildringen), men de er alle skildrede billeder, som har deres autor, bæreren af det rene, skildrende princip. Vi kan tale om en ren autor til forskel fra den autor som er delvis skildret, vist, som indgår i værket som en del af det.

Problemet autor til den mest almindelige, standardiserede dagligdags ytring. Vi kan skabe et billede af enhver talende, vi kan fornemme ethvert ord, enhver tale som objekt, men dette objekt indgår ikke i selve den talendes hensigt og opgave, og skabes ikke af ham som autor til sin egen ytring.

Det betyder ikke, at der ikke findes veje fra den rene autor til forfatteren som menneske - selvfølgelig findes de, og desuden går de ind i selve kernen, ind i selve menneskets dybde, men denne kerne kan aldrig blive et af billederne i selve værket. Forfatteren som menneske er $\mathbf{i}$ det som en helhed, og $\mathbf{i}$ højeste grad, men han kan aldrig blive en integreret billedlig del af det (objekt). Det er hverken natura creata (den skabte natur), eller natura naturata et creans (den avlede og skabende natur), men ren natura creans et non creata (den skabende og ikke skabte natur). ${ }^{9}$

I hvor høj grad er rene, objektløse, enstemmige ord mulige i litteraturen? 
Kan et ord, i hvilket autor ikke hører en fremmed stemme, i hvilket der kun er ham og hele ham, blive byggemateriale til et litterært værk? Er en eller anden grad af ikke-bogstavelighed ikke en nødvendig betingelse for enhver stil? Stâr autor ikke altid uden for sproget som materiale for det kunstneriske værk? Er enhver forfatter (selv den rene lyriker) ikke altid 'dramaturg' i den forstand, at han fordeler alle ord på fremmede stemmer, herunder også forfatterbilledet (og autors andre masker)? Måske er ethvert bogstaveligt, objektløst, enstemmigt ord naivt og udueligt for den ægte kunstneriske skæbne. Enhver ægte, kunstneriske stemme kan altid kun vare en anden stemme i ordet. Kun den anden stemme - et rent forhold - kan fuldt ud være objektløs, bogstavelig og ikke kaste en billedlig, substantiel skygge. Forfatteren er den, som kan arbejde ved hjælp af sproget, mens han selv befinder sig uden for sproget, den som besidder den gave at kunne tale indirekte.

At udtrykke sig selv betyder at gøre sig selv til objekt for en anden og for sig selv ('bevidsthedens virkelighed'). Det er objektiviseringens første trin. Men man kan desuden udtrykke sit forhold til sig selv som objekt (objektiviseringens andet trin). Herved bliver ens eget ord til et objektord (dvs. ikkebogstaveligt ord) og făr en anden - også sin egen - stemme. Men denne anden stemme kaster ikke længere sin skygge (fra sig), fordi den udtrykker et rent forhold, og alt det objektiviserende og materialiserende i ordet bliver afleveret til den første stemme.

Vi udtrykker vores holdning over for den, som ville tale sådan. I dagligdags tale finder dette sit udtryk $i$ en let hånlig eller ironisk intonation (Karenin hos L.Tolstoj ${ }^{10}$ ), forbavset, uforstående, spørgende, tvivlende, bekræftende, forkastende, rasende, begejstret og så videre intonation. Dette er en temmelig primitiv og meget almindelig form for tostemmighed i dagligdags tale, i dialoger og disputter om videnskabelige og andre ideologiske temaer. Det er ganske grov og lidet generaliserende tostemmighed, tit direkte personlig: en af de tilstedeværende samtalepartneres ord reproduceres med ændret accentuering. En lige så grov og lidet generaliserende form er forskellige slags parodisk stilisering. Den fremmede stemme er begrænset, passiv, og der findes ikke dybde og produktivitet (skabende, berigende) i stemmernes indbyrdes forhold. I litteraturen gælder det for positive og negative figurer.

I alle disse former dukker bogstavelig og, kan man sige, fysisk tostemmighed op.

Mere indviklet forholder det sig med autors stemme i drama, hvor den, sandsynligvis, ikke realiseres i ordet.

At se og forstå autor til et værk betyder at se og forstå en anden, fremmed bevidsthed og dens verden, dvs. et andet subjekt (»Du«). Ved forklaring er der 
kun én bevidsthed, ét subjekt; ved forstäelse - to bevidstheder, to subjekter. Der kan ikke være et dialogisk forhold til objektet, derfor er forklaring fri for dialogiske momenter (bortset fra det formelt-retoriske). Forståelse er altid til en vis grad dialogisk.

Forskellige typer og former for forståelse. Forståelse af tegnenes sprog, dvs. forståelse (tilegnelse) af et bestemt tegnsystem (f.eks. et bestemt sprog). Forståelse af et værk på et allerede kendt, dvs. allerede forstået, sprog. Fravær i praksis af skarpe grænser og overgange fra én form for forstăelse til en anden.

Kan man sige, at forståelse af et sprog som system er subjektløs og helt fri for dialogiske momenter? I hvilken grad kan man tale om, at sprog som system har et subjekt? Dechifrering af et ukendt sprog: indsattelse af mulige ikke-definerede 'talende', konstruering af mulige ytringer på dette sprog.

Forståelse af ethvert værk på et sprog vi kender godt (måske ligefrem modersmålet) beriger også altid vores forståelse af dette sprog som system.

Fra sprogets subjekt til værkernes subjekter. Forskellige overgangstrin. Subjektet i forskellige sprogstile (embedsmand, købmand, videnskabsmand osv.). Autors masker (forfatterbilleder) og autor selv.

Socialt-stilistisk billede af en fattig embedsmand, titulærråd (Devusjkin, for eksempel). Et sådant billede er givet, skønt ved hjælp af selvafsløring, som han (tredje person) og ikke som $d u$. Han er et objekt og et type-eksemplar. Til billedet af ham er der endnu ikke et agte dialogisk forhold.

Tilnærmelse af fremstillingsmidlerne til fremstillingsobjektet som kendetegn for realisme (selvkarakteristikker, stemmer, sociale stillejer, ikke skildring, men citering af helte som talende mennesker).

Objektmæssige og rent funktionelle elementer i enhver stil.

Problemet at forstå en ytring. Netop for at kunne forstå er det nødvendigt først og fremmest at etablere principielle og skarpe grænser for ytringen. Udskiftning af talesubjekter, evnen til at bestemme svaret. Enhver forståelse er principielt set et svar. 'Kannitverstan',"

Når der forsætligt (bevidst) er mange stillejer, opstår der altid dialogiske forhold mellem dem. ${ }^{2}$ Man kan ikke forstå disse vekselvirkningsforhold rent lingvistisk (eller endog mekanisk).

Den rent lingvistiske (og dermed den rent deskriptive) beskrivelse og definition af forskellige stillejer inden for rammerne af et værk kan ikke afsløre deres meningsmæssige (herunder også kunstneriske) vekselvirkningsforhold. Det er vigtigt at forstå den totale mening med denne dialog mellem stillejer ud fra forfatterens synspunkt (ikke som billede, men som funktion). Men năr man taler om tilnærmelsen af midlerne til fremstilling og fremstillingens genstand, så er det objektet, man forstår ved det skildrede, og ikke et andet subjekt $(d u)$. 
Skildringen af en ting og skildringen af et menneske (hvis væsen det er at tale). Realismen tingsliggør ofte mennesket, men dette er ikke en tilnærmelse til ham. Naturalismen med dens tendens til kausal forklaring af menneskets handlinger og tanker (dets meningsmæssige position i verden) tingsliggør mennesket i endnu højere grad. Den 'induktive' tilgang, som formodentlig er karakteristisk for realismen, tingsliggør i sit væsen og forklarer mennesket kausalt. Stemmer (som tingsliggjorte sociale stillejer) forvandles herved bare til kendetegn for ting (eller symptomer på processer), dem kan man ikke længere svare, med dem kan man ikke længere diskutere, de dialogiske forhold til sådanne stemmer slukkes.

Skildringen af mennesket i litteraturen som objekt og subjekt kan være af vidt forskellig grad (resp. autors dialogiske forhold til dem). I denne henseende er billedet af Devusjkin principielt forskelligt fra objekt-billeder af fattige embedsmænd hos andre forfattere. Og han er polemisk tilspidset mod de billeder, hvori der ikke findes et ægte dialogisk $d u$. I romaner gives der sædvanligvis helt lukkede og fra forfatterens side opsummerede disputter (hvis der da overhovedet gives disputter). Hos Dostojevskij er der stenogrammer af uafsluttet og uafsluttelig disput. Men også i det hele taget er enhver roman fuldt af dialogiske overtonèr (selvfølgelig ikke altid med dens helte). Efter Dostojevskij erobrer polyfonien hele verdenslitteraturen.

Hvad mennesket angår, er kærlighed, had, medlidenhed, bevægelse, og i det hele taget alt det emotionelle, altid til en vis grad dialogisk.

I det dialogiske overskrider Dostojevskij (resp. hans helte som subjekter) en vis grænse, og det dialogiske får en ny (højere) status.

Billedet af mennesket som objekt er ikke ren tingslighed. Man kan elske det, have medlidenhed med det osv., men det vigtigste er, at man kan (og skal) forstå det. I skønlitteratur (som i det hele taget i kunsten) ligger der selv på døde ting (som har med mennesket at gøre) genskin af subjektet.

Tale forstået som objektets (og objektets tale kræver nødvendigvis forstảelse - ellers ville det ikke være tale - men i denne forståelse er det dialogiske moment svækket) kan være inkluderet i den kausale kæde af forklaringen. Den objektløse tale (rent idemæssig, funktionel) forbliver i den uafsluttede genstand-orienterede dialog (f.eks. videnskabelig undersøgelse).

Sammenstilling af ytringer i form af måleresultater i fysik.

Teksten som subjektiv refleksion af den objektive verden, teksten som et udtryk for bevidsthed, som reflekterer et eller andet. Når teksten bliver objekt for vores erkendelse, kan vi tale om refleksionen af en refleksion. Forståelsen af teksten er bare en korrekt refleksion af en refleksion. Gennem en andens refleksion til det reflekterede objekt.

Ikke et eneste naturfænomen har 'betydning', kun tegn (herunder ord) har 
betydninger. Derfor begynder ethvert studie af tegn med forståelse, uanset hvilken retning det så senere har taget.

Teksten - det oprindeligt givne (realitet) og udgangspunkt for enhver humanistisk disciplin. Konglomerat af mangfoldige kundskaber og metoder, som kaldes filologi, lingvistik, litteraturvidenskab, videnskabsteori osv. Med udgangspunkt i teksten vandrer disse discipliner i forskellige retninger, fravrister forskelligartede stykker fra naturen, samfundslivet, psyken, historien, forener dem snart med kausale, snart med meningsmæssige bånd, blander konstateringer med vurderinger. Fra henvisningen til det reelle objekt er det nødvendigt at gå over til tydelig afgrænsning af genstandene for den videnskabelige undersøgelse. Det reelle objekt er et socialt (samfunds-) menneske, som taler og udtrykker sig med andre midler. Kan man finde en eller anden tilgang til mennesket og dets liv (arbejde, kamp), bortset fra gennem de tegn-tekster, som det har skabt eller er i gang med at skabe? Kan man iagttage og studere mennesket som et naturfænomen, som en ting? Menneskets fysiske ageren skal forstås som handling, men man kan ikke forstå handlingen uden for dens mulige (af os rekonstruerede) tegnudtryk (motiver, mål, stimuli, grad af bevidsthed osv.). På en måde tvinger vi mennesket til at tale (vi konstruerer dets vigtigste vidnesbyrd, forklaringer, bekendelser, tilståelser, vi færdigudvikler en virkelig elIer en mulig indre tale osv.). Overalt er der en virkelig eller en mulig tekst og forståelsen af den. Undersøgelsen bliver til spørgen og samtale, dvs. til dialog. Vi spørger ikke naturen, og den svarer os heller ikke. Vi stiller spørgsmål til os selv og organiserer på en bestemt måde iagttagelsen eller eksperimentet, for at få et svar. Idet vi studerer mennesket, søger og finder vi overalt tegn og prøver at forstå deres betydning.

$\mathrm{Vi}$ interesserer os først og fremmest for konkrete teksttyper og for teksternes konkrete livsbetingelser, deres indbyrdes forhold og indbyrdes handling.

De dialogiske forhold mellem ytringer, som også gennemtrænger de enkelte ytringer indefra, hører under metalingvistik. De adskiller sig grundlæggende fra alle mulige lingvistiske forhọld mellem elementer både i sprogsystemet og i den enkelte ytring.

Ytringens (taleværkets) metalingvistiske karakter.

De meningsmæssige bånd inden for en ytring (selv en potentielt uendelig ytring, f.eks. i videnskabssystemet) har genstandsmæssig og logisk karakter ( $\mathrm{i}$ ordets brede forstand), men de meningsmæssige bånd mellem forskellige ytringer får dialogisk karakter (eller, i hvert fald, dialogisk nuance). Ideerne er fordelt mellem forskellige stemmer. Stemmen, personligheden er af enestående betydning.

De lingvistiske elementer er neutrale i forhold til deres fordeling på ytringer, de bevæger sig frit uden at anerkende ytringens grænser og uden at aner- 
kende (eller respektere) stemmernes suverænitet.

Hvad er det så, der definerer ytringens urokkelige grænser? Det er de metalingvistiske kræfter.

De ikke-litterære ytringer og deres grænser (replikker, breve, dagbøger, indre tale osv.), overført til et litterært værk (f.eks. en roman). Her ændres deres totale mening. Andre stemmer genspejles nu i dem, og selve autors stemme găr ind $\mathbf{i}$ dem.

To sammenstillede fremmede ytringer, som intet kender til hinanden, hvis de blot strejfer det samme tema (den samme tanke), indtræder uundgåeligt i et dialogisk forhold med hinanden. De berører hinanden på det fælles temas, den fælles tankes territorium.

Epigrafik. Genreproblemet vedr. de ældste inskriptioner. Inskriptionernes autor og adressat. Obligatoriske skabeloner. Gravskrifter ('Fryd dig'). Den dødes henvendelse til den levende, der går forbi. De obligatoriske skabelonagtige former for slægtsmottoer, besværgelser, bønner osv. Former for lovprisning og forherligelse. Former for bespottelse og skældsord (rituelle). Problemet ordets forhold til tanke, til ønske, vilje og krav. Magiske forestillinger om ordet. Ordet som gerning. Hele omvæltningen i ordets historie, da det blev til udtryk for ren (handlingsløs) information (kommunikation). Oplevelse af ens eget og den andens tilstedeværelse i ordet. Den sene forfatterbevidstheds tilblivelse.

Forfatteren til et litterær værk (roman) skaber et enkeltstående og helt taleværk (ytring). Men han skaber det af forskelligartede, på en måde fremmede ytringer. Og selv autors direkte tale er fuld af bevidst fremmede ord. Ikke-direkte talen, når forholdet til ens eget sprog er som til et ud af flere mulige sprog (og ikke som det absolutte og eneste mulige sprog).

Fuldstændige, eller 'lukkede', ansigter i malerkunst (herunder også i portrætkunst). De viser et menneske færdiggjort, et menneske, som allerede er helt og ikke kan blive andet. Ansigter på mennesker, som allerede har sagt alt, (eller) som, på en måde, er døde. Kunstneren koncentrerer sin opmærksomhed på de fuldstændiggørende, definerende og afsluttende træk. Vi ser et helt menneske og forventer intet mere (og intet andet) af det. Mennesket kan ikke laves om, fornys, gennemgå en metamorfose - dette er dets definitive (sidste og afgørende) stadie.

Autors forhold til det skabte indgår altid i billedsammensætningen. Autors holdning er billedets konstruerende moment. Denne holdning er yderst indviklet. Det er utilladeligt at reducere den til ligefrem vurdering. Sådanne ligefremme vurderinger ødelægger det kunstneriske billede. De findes ikke engang i god satire (hos Gogol', hos Sjtjedrin). For forste gang at se, for første gang at erkende noget - betyder allerede at indtræde $\mathbf{i}$ et forhold til det: det 
eksisterer ikke i sig selv og for sig selv, men for en anden (dvs. to sammenstillede bevidstheder). Forståelse er allerede et meget vigtigt forhold (forståelse er aldrig tautologi eller dublering, fordi der allerede er to og en potentiel tredje). Tilstanden ikke at blive hørt og ikke at blive forstået (se T.Mann nedenfor). 'Jeg ved ikke', 'Sådan var det, og desuden hvad kommer det mig ved' - er vigtige forhold. $\varnothing$ delæggelsen af de med genstanden sammenvoksede ligefremme vurderinger og i det hele taget $\emptyset$ delæggelsen af forhold skaber et nyt forhold. En sæerlig form for emotionel-evaluerende forhold. Deres mangfoldighed og indviklethed.

Autor må ikke adskilles fra billeder og personer, eftersom han indgår i dem som en ubestridelig del af dem (billederne er tosidede og af og til tostemmige). Men forfatterbilledet kan adskilles fra personbillederne; men dette billede er selv skabt af forfatteren og derfor ogsâ tosidet. Ofte, i stedet for personbilleder, mener man på en måde levende mennesker.

De forskellige meningsmæssige planer, i hvilke personers og og autors tale ligger. Personerne taler som deltagere i det skildrede liv, de taler, så at sige, ud fra private positioner, deres synspunkter er på en eller anden måde begrænsede (de ved mindre end autor). Autor er uden for den skildrede (og i en vis forstand af ham skabte) verden. Han betragter hele denne verden fra højere og kvalitetsmæssigt anderledes positioner. Endelig er alle personer og deres tale genstand for autors holdning (og autors tale). Men planet for persontale kan krydse planet for autors tale, dvs. det er muligt at dialogiske forhold opstår mellem dem. Hos Dostojevskij, hvor personerne er ideologer, ender autor og sådanne helte (tænkere, ideologer) på samme plan. Dialogiske kontekster og personernes og autors talesituation cr vasentlig forskellige. Personernes tale deltager i de skildrede dialoger i værket og indgår ikke direkte i samtidens reelle ideologiske dialog, dvs. et reelt talesamvær, i hvilket værket i sin helhed deltager og begribes (personernes tale deltager i det reelle talesamvær kun som element i værket som helhed). Imidlertid deltager autor i netop denne reelle dialog og bestemmes af samtidens reelle situation. Til forskel fra den reelle forfatter er det af ham skildrede forfatterbillede berøvet den direkte deltagelse i den reelle dialog (forfatterbilledet deltager kun i denne dialog via værket som helhed), til gengæld kan det deltage i varkets sujet og i den skildrede dialog med personerne ('autors' samtale med Onegin). Den skildrende (reelle) forfatters tale, hvis den eksisterer, er en principielt særlig taletype, som ikke kan befinde sig på samme plan som personernes tale. Netop den (den reelle forfattertale) afgør værkets enhed og dets sidste indholdsmæssige instans, dets, om man så må sige, sidste ord.

V.V.Vinogradov definerer forfatterbilleder og personbilleder som sprogstillejer; forskellene på dem indskrankes til sprog- og stilforskelle, dvs. til rent 
lingvistiske forskelle. Vinogradovs koncept dækker ikke de ikke-lingvistiske vekselvirkningsforhold mellem dem. Men disse billeder (sprog-stillejer) i værket befinder sig jo ikke ved siden af hinanden som noget lingvistisk givet, de indgår her i en særlig type dynamiske meningsmæssige forhold. Denne type af forhold kan man definere som dialogiske. Dialogiske forhold har en specifik karakter. De kan hverken reduceres til rent logiske (end ikke dialektiske) eller til rent lingvistiske (kompositionelle-syntaktiske) forhold. De er kun mulige mellem hele ytringer hos forskellige talesubjekter (dialog med sig selv har en sekundær og i de fleste tilfælde kunstlet karakter). Vi berører ikke her spørgsmålet om termen 'dialog's oprindelse (se Hirzel ${ }^{13}$ ).

Der, hvor der ikke er ord, hvor der ikke er sprog, kan der heller ikke være dialogiske forhold; de kan ikke eksistere mellem genstande eller logiske størrelser (begreber, propositioner osv.). Dialogiske forhold forudsætter et sprog, men de findes ikke i sprogsystemet. De er umulige mellem sprogelementer. Det specifikke ved dialogiske forhold kræver en særlig undersøgelse.

En snæver forståelse af dialogen som en af de kompositionelle taleformer (dialogisk og monologisk tale). Man kan sige at enhver replik i sig selv er monologisk (den mindste mulige monolog), men enhver monolog er en replik i en stor dialog (i et talesamvær i en bestemt sfære). Monolog som tale der ikke er adresseret til nogen og ikke forudsætter noget svar. Tale kan være monologisk i forskellig grad.

Dialogiske forhold - det er (meningsmæssige) forhold mellem alle mulige ytringer i talesamvær. Lige meget hvilke to ytringer vi sammenstiller på et meningsmæssigt plan (ikke som ting eller lingvistiske eksempler), vil de indgå $i$ et dialogisk forhold. Men dette er en særlig form for uforsætlig dialog (f.eks. udvalg af forskellige ytringer fra forskellige videnskabsmænd eller lærde fra forskellige epoker om det samme spørgsmål).

'Sult, kulde!' - er en ytring udtalt af et talesubjekt. 'Sult!' - 'Kulde!' - er to dialogisk sammenstillede ytringer udtalt af to forskellige talesubjekter; her opstår dialogiske forhold, som ikke var der i første tilfælde. Det samme med to udvidede sætninger (udtænke et overbevisende eksempel!).

Når man tager en ytring for at foretage en lingvistisk analyse af den, ses der bort fra dens dialogiske natur, man betragter den i sprogsystemet (som realisering af det) og ikke i talessamværets store dialog.

Talegenrernes enorme og hidtil uudforskede mangfoldighed: fra de upublicerede sfærer af indre tale til kunstneriske værker og videnskabelige traktater. Mangfoldigheden af vulgærgenrer (se Rabelais), ${ }^{14}$ intimgenrer osv. Etablering af sproget sker i forskellige epoker i forskellige genrer.

Sproget, ordet, det er næsten alt i menneskets liv. Men denne alt omfattende virkelighed med mange facetter er ikke nødvendigvis objekt for kun en viden- 
skab, lingvistikken, og den kan ikke forstås kun ved hjælp af de lingvistiske metoder. Objekt for lingvistikken er kun materiale, kun midler for talesamvær, men ikke selve talesamværet, ikke ytringer i sig selv og ikke (dialogiske) forhold mellem dem, ikke former for talesamvær og ikke talegenrer.

Lingvistikken undersøger kun forholdene mellem elementer inden for sprogsystemet og ikke forholdene mellem ytringer og ikke ytringernes forhold til virkeligheden og til den talende person (autor).

I forhold til de reelle ytringer og til de reelle talende har sprogsystemet ren potentiel karakter. Og ordets betydning, så længe den undersøges lingvistisk (lingvistisk semaseologi), defineres kun ved hjælp af andre ord fra det samme sprog (eller et andet sprog) i sit forhold til dem; forholdet til et begreb eller et kunstnerisk billede eller til den reelle virkelighed får det kun i ytringen og gennem ytringen. Sådan er ordet som objekt for lingvistikken (og ikke det reelle ord som konkret ytring eller del af den, del af den, og ikke middel).

Begynde med problemet omkring taleværket som en primær realitet i talens liv. Fra dagligdags replik til mangebinds-roman eller videnskabelig afhandling. Vekselvirkningsforholdet mellem taleværker i taleprocessens forskellige sfærer. 'Den litterære proces', kampen mellem meninger, den ideologiske kamp osv. Når to taleværker, ytringer, bliver stillet over for hinanden, indgâr de i særlige meningsmæssige forhold, som vi kalder dialogiske. Deres særlige natur. Sprogelementer inden for sprogsystemet eller inden for 'teksten' (i streng lingvistisk forstand) kan ikke indgå i dialogiske forhold. Kan sprog, dialekter (regionalsprog, sociolekter og jargoner), sproglige (funktionelle) stillejer (lad os sige familiærdagligdags tale og videnskabeligt sprog osv.) indgå i sådanne forhold? Kun hvis man betragter dem ikke-lingvistisk, dvs. kun hvis de transformeres til verdensanskuelse (eller nogle sproglige eller kommunikative oplevelser af verden), til 'synspunkter', til 'sociale stemmer' osv.

En sådan transformation udfører kunstneren, når han skaber typiske eller karakteristiske ytringer hos typiske personer (selv når de ikke er personificerede og ikke har navn), en sådan transformation (på et lidt andet plan) udfører den æstetiske lingvist (Vosslers skole, især måske Spitzers sidste arbejde ${ }^{15}$ ). Ved sådanne transformationer får sproget en slags 'autor', et talesubjekt, en kollektiv udøver (et folk, en nation, en profession, en social gruppe osv.). En sådan transformation betegner en overskridelse af grcenserne for lingvistikken (i den strenge og præcise forståelse af denne). Er sådanne transformationer berettigede? Ja, de er berettigede, men kun under strengt definerede forhold (for eksempel i litteraturen, især i romanen, hvor vi ofte finder dialoger mellem 'sprog' og sproglige stillejer) og kun under forudsætning af streng og klar metodologisk bevidsthed. Derimod er sådanne transformationer utilladelige, 
når man på den ene side tager sproget som et ikke-ideologisk (og ikke-personligt) lingvistisk system, og på den anden side indsmugler den social-ideologiske karakteristik af sprog og stilarter (delvis hos V.V.Vinogradov). Dette spørgsmål er meget kompliceret og interessant (for eksempel i hvor høj grad kan man tale om sprogets subjekt, eller en sproglig stilarts talesubjekt, eller om billedet af videnskabsmanden bag det videnskabelige sprog, eller om billedet af forretningsmanden bag forretningssproget, billedet af bureaukraten bag kancellisproget osv.).

De dialogiske forholds egenartede natur. Problemet indre dialogisme. Det skarpe skel mellem ytringer. Problemet det tostemmige ord. Forståelse som dialog. Vi nærmer os her sprogfilosofiens og i det hele taget den humanistiske tankegangs yderste kant, uberørt land. En ny problematisering af forfatteridentiteten (den skabende personlighed).

Det givne og det skabte i taleytringer. Ytringen er altid kun genspejling eller udtryk for noget, som allerede eksisterer, er givet og færdigt, uden for den. Den skaber altid noget, der ikke eksisterede før den, noget absolut nyt og $\mathbf{u}-$ igentageligt, og noget som, udover det, altid har værdi (sandhed, godhed, skønhed osv.). Men noget skabt skabes altid af noget givet (sprog, et iagttaget virkelighedsfænomen, en gennemlevet følelse, selve det talende subjekt, det færdige i dets verdensanskuelse osv.). Alt givet forvandles til det skabte. Analyse af den enkleste dagligdags dialog ('Hvad er klokken?' - 'Den er syv'.) Den mere eller mindre indviklede situation omkring spørgsmålet. Det er nødvendigt at se på uret. Svaret kan være rigtigt eller forkert, det kan have betydning osv. Hvad slags tid; det samme spørgsmål stillet ude i rummet osv.

Ord og bøjningsformer som forkortelser eller repræsentanter for virkelige eller mulige ytringer, verdensanskuelser, synspunkter osv. Muligheder og perspektiver, som ligger i ordet, de er egentligt uendelige.

Dialogiske grænser krydser hele området for levende menneskelig tænkning. Den humanistiske tænknings monologisme. Lingvisten er vant til at opfatte alt $i$ en eneste isoleret kontekst (i sprogsystemet eller i en lingvistisk forståelse af teksten, ikke korreleret dialogisk med en anden, tilsvarende tekst), og som lingvist har han selvfølgeligt ret. Dialogismen i vores tænkning om værker, teorier, ytringer, i det hele taget i vores tanker om mennesker.

Hvorfor er indirekte tale accepteret, men dens forståelse som tostemmigt ord ikke accepteret?

At studere det givne i det skabte (for eksempel sprog, fælles og færdige elementer i verdensanskuelse, virkelighedens genspejlede synspunkter osv.) er betydeligt lettere end at studere selve det skabte. Ofte indskrænkes hele den videnskabelige analyse til en afdækning af alt det før værket givne, allerede forhåndenværende og færdige (det som ikke er skabt, men fundet af kunstne- 
ren som færdigt). Alt givet skabes på en måde på ny i det skabte, forvandles i det. Indskrænkelse til det, som i forvejen er givet og færdiggiort. Genstanden er færdiggjort, de sproglige midler til dens fremstilling er færdiggjorte, selve kunstneren er givet, hans verdensanskuelse er givet. Og så ved hjælp af de givne midler, i lyset af den givne verdensanskuelse fremstiller den givne digter den færdiggjorte genstand. Men faktisk skabes både genstanden og selve digteren, hans verdensanskuelse og udtryksmidlerne i skabelsesprocessen.

Ordet, brugt i gåseøjne, dvs. følt og brugt som noget fremmed, og det samme ord (eller et eller andet andet ord) uden gåseøjne. De uendelige niveaunuanceringer af det at være fremmed (eller det at være ens eget) mellem ordene, deres forskellige afstande fra den talende. Ordene er fordelt på forskellige planer i forskellige afstande fra forfatterordets plan.

Ikke kun den indirekte tale, men forskellige former for skjult, halvskjult, spredt fremmed tale osv. ${ }^{16}$ Alt dette forblev ubrugt.

Når man i sprog, jargoner og stillejer begynder at høre stemmer, holder de op med at være potentielt udtryksmiddel og bliver aktuelt, realiseret udtryk; en stemme er gået ind i dem og styrer dem. De er bestemt til at spille deres eneste og uigentagelige rolle i tale-(skaber-) samvær.

Sprog og stilarters gensidige belysning. Forholdet til ting og forholdet til mening, personificeret i ordet eller i et eller andet tegnmateriale. Forholdet til tingen (i dens rene tingslighed) kan ikke være dialogisk (dvs. samtale, uenighed, enighed, osv.). Forholdet til meningen er altid dialogisk. Forståelse er i sig selv dialogisk.

Meningens tingsliggørelse, for at inkludere den i en kausal række.

En snæver forståelse af dialogisme som uenighed, polemik, parodi. Det er set udefra de mest tydelige, men grove former for dialogisme. Tiltro til det fremmede ord, ærefrygtig modtagelse (autoritært ord), det at være elev, det at lede efter og fremtvinge den dybeste mening, enighed, dens uendelige gradueringer og nuancer (men ikke logiske restriktioner og ikke rent genstandsmæssige forbehold), aflejring af mening på mening, stemme på stemme, forstærkning ved hjælp af sammensmeltning (men ikke identificering), kombination af mange stemmer (korridor af stemmer), supplerende forståelse, overskridelse af det forståeliges grænser osv. Disse særlige forhold kan hverken indskrænkes til noget rent logisk eller noget rent genstandmæssigt. Her mødes hele positioner, hele personligheder (personlighed kræver ikke ekstensiv afsløring - den kan vise sig i en lyd, afsløres i et ord), nemlig stemmer.

Ordet (i det hele taget ethvert tegn) er interindividuelt. Alt sagt og udtrykt befinder sig uden for den talendes 'sjæl', det tilhører ikke kun ham. Ordet må ikke kun tilhøre den talende. Autor (den talende) har sin ubestridelige ret til ordet, men også tilhøreren har sin ret, og også de, hvis stemmer lyder i det ord 
autor har fundet på forhånd, har deres ret (alle ord tilhører jo nogen). Ordet er et drama med tre deltagere (det er ikke en duet, men en trio). Dramaet udspilles uden for autor, og det er utilladeligt at 'introjektere' (introjektion) det i autor.

Hvis vi ikke forventer noget af ordet, hvis vi i forvejen ved alt, hvad det kan sige, så går ordet ud af dialogen og bliver tingsliggjort.

Selvobjektivering (i lyrik, i bekendelser osv.) som fremmedgørelse og til en vis grad overvindelse af sig selv. Når jeg objektiverer mig selv, (dvs, sætter mig uden for mig selv), får jeg mulighed for et ægte dialogisk forhold til mig selv.

Kun en ytring har et umiddelbart forhold til virkeligheden og til det levende talende menneske (subjektet). I sproget er der kun potentielle muligheder (skemaer) for disse forhold (stedord, tids- og modalformer, leksikalske midler osv.). Men ytringen bestemmes ikke kun ved sit forhold til genstanden og til det talende forfattersubjekt (og ved sit forhold til sproget som system af potentielle muligheder, det givne), men, hvilket er vigtigst af alt for os, den bestemmes ved sit direkte forhold til andre ytringer inden for grænserne af en given komunikations-sfire. Uden for dette forhold eksisterer ytringen ikke reelt (kun som tekst). Kun ytringen kan være rigtig (eller forkert), ægte, sand, (falsk), smuk, retfærdig osv.

Forståelse af et sprog og forståelse af en ytring (inklusive det implicitte svar og dermed vurdering).

Vi er ikke interesserede i den psykologiske side af forholdet til (og forståelsen af) de fremmede ytringer, men i hvordan denne psykologiske side genspejles i selve ytringens struktur.

I hvor høj grad kan lingvistiske (rene) definitioner af sproget og dets elementer bruges til kunstnerisk-stilistisk analyse? Disse termer kan kun tjene som udgangspunkt for beskrivelse. Men de kan ikke beskrive, de kan ikke rumme det vigtigste. Det er jo ikke sprogsystemets elementer (enheder), som er blevet tekstelementer her, men ytringsmomenter.

Ytringen som meningsmassigt hele.

Man kan hverken løsrive forholdet til andres ytringer fra forholdet til en genstand (det er jo om den man er uenig, enig, i den man kommer i berøring med hinanden), eller fra forholdet til den talende selv. Det er en levende treenighed. Men det tredje moment er indtil nu normalt ikke blevet taget i betragtning. Men også der, hvor det er blevet taget i betragtning (ved analyse af den litterære proces, af den publicistiske genre, af polemik, af kampen mellem videnskabelige meninger), er den særlige natur ved forhold til andre ytringer som ytringer, dvs. meningsmæssige helheder, forblevet uafsløret og uudforsket (man har forstået disse forhold abstrakt, genstand-logisk, eller psykolo- 
gisk, eller endog mekanisk-kausalt). Man har ikke forstået den særlige, dialogiske natur ved det gensidige forhold mellem meningsmæssige helheder, meningsmæssige positioner, dvs. ytringer.

Eksperimentatoren udgør en del af det eksperimentelle system (i mikrofysik). Man kan sige, at også den, der forstår (modtageren), udgør en del af den forståede ytring, tckst (mere præcist, en del af ytringer, af dialogen mellem dem, hvori den, der forstår, indgår som en ny deltager). Det dialogiske møde mellem to bevidstheder i de humanistiske videnskaber. Den dialogiserende kontekst indrammer den fremmede ytring. For selv idet vi giver en kausal forklaring på en fremmed ytring, forkaster vi den. Tingsliggørelse af fremmede ytringer er et særligt (falsk) middel til at modbevise dem. Hvis man forstår en ytring som en mekanisk reaktion, og en dialog som kæde af reaktioner (i deskriptiv lingvistik eller hos behavioristerne), så hører i samme grad sande så vel som falske ytringer, geniale så vel som talentløse værker, ind under en sådan forståelse (der vil kun være en forskel i de mekanisk forståede effekter, nytte osv.). Dette synspunkt, som er relativt berettiget, i lighed med et rent lingvistisk synspunkt (trods alle forskelligheder mellem dem), berører ikke ytringens væsen som meningsmæssig helhed, meningsmæssigt synspunkt, meningsmæssig position osv. Enhver ytring prætenderer retfærdighed, æegthed, skønhed, sandfærdighed (billedlig ytring) osv. Og disse værdier ved ytringerne bestemmes ikke ved deres forhold til sproget (som rent lingvistisk system), men af forskellige former for forhold til virkeligheden, til det talende subjekt og til de andre (fremmede) ytringer (bl.a. til dem, som vurderer dem som ægte, skønne osv.).

Lingvistik har at gøre med tekster, men ikke med værker. Det, som den siger om værkerne, bliver indsmuglet, dvs. det fremgår ikke af den rent lingvistiske analyse. Selvfølgelig har selve denne lingvistik lige fra begyndelsen sædvanligvis karakter af konglomerat og er mættet med ikke-lingvistiske elementer. Mere enkelt sagt er rent lingvistiske forhold (dvs. lingvistikkens objekt) et tegns forhold til et andet og til flere tegn inden for sprogsystemets eller tekstens grænser (dvs. system eller lineære forhold mellem tegn). Ytringernes forhold til den reelle virkelighed, til det reelle talende subjekt og til andre reelle ytringer; dvs. de forhold, der for første gang gør ytringerne sande eller falske, smukke osv., kan aldrig blive objekt for lingvistikken. Enkelte tegn, sprogsystemer eller tekster (som tegnenheder) kan aldrig være sande, eller falske, eller smukke osv.

Enhver stor og kunstnerisk verbal enhed er et meget indviklet niveauinddelt system af forhold. Ved et kunstnerisk forhold til sprog findes der ikke 'ingens', stemmeløse ord. I ethvert ord er der stemmer, af og til uendeligt fjerne, anonyme, næsten upersonlige (stemmer af leksikalske nuancer, af stilarter 
osv.), næsten ikke til at fă fat på, og stemmer som klinger tæet, næsten samtidigt.

En hvilken som helst levende, kompetent og upartisk iagttagelse fra en hvilken som helst position, fra et hvilket som helst synspunkt bevarer altid sin vardi og sin betydning. Ensidighed og begrænsning i et synspunkt (iagttagerens position) kan altid blive korrigeret, suppleret og transformeret (overført) ved hjælp af iagttagelser fra andre synspunkter. Blotte synspunkter (uden levende og nye iagttagelser) er frugtesløse.

Pusjkins kendte aforisme om leksikon og bøger. ${ }^{17}$

Angående problemet dialogiske forhold. Disse problemer er i bund og grund saregne og kan ikke indskrankes til hverken logiske, eller lingvistiske, eller psykologiske, eller mekaniske, eller nogen andre naturforhold. Det er en særlig type af meningsmassige forhold, hvis medlemmer kun kan være hele ytringer (enten betragtet som hele eller potentielt hele), bag hvilke der altid står (og i hvilke der udtrykker sig) et reelt eller potentielt talesubjekt, autor af givne ytringer. En reel dialog (dagligdags samtale, videnskabelig diskussion, politisk uenighed osv.). Forhold mellem replikkerne $i$ en sådan dialog er udefra set den tydeligste og enkleste form for dialogiske forhold. Men dialogiske forhold falder selvfølgelig ikke sammen med forholdene mellem replikkerne $i$ en reel dialog, de er langt bredere, mere forskelligartede og mere indviklede. To ytringer, som ligger fjernt fra hinanden, både i tid og rum, og som intet ved om hinanden, viser ved meningsmæssig sammenstilling dialogiske forhold, hvis der mellem dem er bare den mindste meningsmæssige konvergens (selv om der kun er et delvis fællesskab i tema, synspunkt osv.). En hvilken som helst historisk oversigt over et eller andet videnskabeligt spørgsmål (selvstændigt eller indeholdt i et videnskabeligt arbejde om det pågældende spørgsmål) producerer dialogiske sammenstillinger (af ytringer, meninger, synspunkter), også af ytringer fra videnskabsmand, som intet kendte til hinanden og heller ikke kunne gøre det. Det, at problemet er det samme, avler her dialogiske forhold. 'De dødes dialoger' i skønlitteratur (Lukian, det XVII årh.). I overensstemmelse med litterær specificitet gives der her en opdigtet situation af et møde i det hinsides. Et modsat eksempel - den i komik ofte brugte situation med en dialog mellem to døve, hvor den reelle dialogiske kontakt er klar, men hvor der ikke er nogen meningsmæssig kontakt mellem replikkerne (eller der er en imaginær kontakt). Nul-dialogiske forhold. Her afsløres den tredjes synspunkt i dialogen (han deltager ikke i dialogen, men forstår den). Forståelse af hele ytringen er altid dialogisk.

På den anden side kan man ikke forstå dialogiske forhold forenklet og ensidigt, og det gør man, når man indskrænker dem til modsigelse, kamp, diskussion, uenighed. Enighed er en af de vigtigste former for dialogiske forhold. 
Enighed er meget rig på nuancer og variationer. To ytringer, som er identiske i alle forhold ('Dejligt vejr!' - 'Dejligt vejr!'), hvis det virkelig er to ytringer, som tilhører to forskellige stemmer og ikke en, er forbundet ved hjælp af dialogiske forhold af enighed. Det er en bestemt dialogisk begivenhed i gensidige forhold mellem to og ikke et ekko. Enighed kunne jo både være der og ikke være der ('Nej, vejret er ikke så godt' osv.).

Dialogiske forhold er således meget bredere end dialogisk tale i snæver forstand. Dialogiske forhold er også altid til stede mellem dybt monologiske taleværker.

Mellem sproglige enheder, hvordan vi end forstår dem, og på hvilket sprogstrukturelt niveau vi end tager dem, kan der ikke være dialogiske forhold (fonemer, morfemer, leksemer, sætninger osv.). En ytring som talehelhed kan ikke erkendes som enhed af det sidste, højeste niveau eller plan i sprogstrukturen (over syntaksen), fordi den indgår i en verden af helt anderledes forhold. (På et vist plan er det kun muligt at sammenstille en hel ytring med et ord.) En hel ytring er ikke mere en sprogenhed (og ikke en enhed af 'en talestrøm' eller 'en talekæde'), men en enhed af talesamvær, hvor den ikke har betydning, men mening (dvs. en helhedsidè, der har forhold til værdi, til ægthed, skønhed osv., og som inkluderer vurdering og kræver responsforståelse). Responsforståelsen af en taleenhed har dialogisk karakter.

Forståelsen af hele ytringer og de dialogiske forhold mellem dem har uvægerligt dialogisk karakter (herunder også den humanistiske forskers forståelse): den, der forstår (herunder også forskeren), bliver selv en del af dialogen, skønt på et særligt plan (afhængigt af forståelsens og undersøgelsens retning). Analogt med inkluderingen af eksperimentatoren i det system han eksperimenterer med (som del af det) eller af iagttageren $i$ den verden han iagttager $i$ mikrofysikken (kvanteteorien). Den iagttagende har ikke nogen position uden for den verden, han iagttager, og hans iagttagelse indgår som bestanddel i det iagttagede objekt.

Dette gælder fuldt ud hele ytringer og forholdene mellem dem. De kan ikke forstås udefra. Selve forstảelisen indgår som dialogisk moment i det dialogiske system og ændrer på en eller anden måde dets totale mening. Den, der forstår, bliver uvægerligt den tredje i dialogen (selvfølgelig ikke i bogstavelig aritmetisk forstand, fordi der kan være et ubegrænset antal deltagere i den forståede dialog udover den tredje), men denne 'tredjes' dialogiske position er en helt særegen position. En hvilken som helst ytring har altid en adressat (der kan være mere eller mindre nær, konkret, bevidstgjort osv.), hvis responsforståelse værkets autor søger og foregriber. Dette er den anden (ikke i aritmetisk forstand). Men bortset fra denne adressat (den anden) forudsætter forfatteren til ytringen mere eller mindre bevidst en højeste overadressat (den tredje), hvis 
absolut retfærdige responsforståelse forudsættes enten i det metafysiske fjerne, eller i en fjern historisk tid (smuthuls-adressat). I forskellige epoker og ved forskellige verdensanskuelser får denne overadressat og hans ideelt rigtige responsforståelse forskellige konkrete udtryk (gud, den absolute sandhed, den upartiske menneskelige samvittighedsdom, folk, historiens dom, videnskab osv.).

Autor kan aldrig overgive sig og sit taleværk helt, fuldt og endeligt til de forhåndenværende eller nære adressater (selv de nærmeste efterkommere kan jo tage fejl), og han forudsætter (mere eller mindre bevidst) en anden højere instans af responsforståelse, som kan fjerne sig i forskellige retninger. På en måde finder enhver dialog sted på baggrund af en responsforståelse fra en usynlig tilstedeværende tredje, som står over alle dialogens deltagere (partnere). (Se forståelsen af det fascistiske fangehul eller af helvede hos T. Mann som den absolute form for $i k k e$ at blive h $\phi r t$, som absolut fravær af den tredje. ${ }^{18}$ )

Den pågxldende tredje er overhovedet ikke noget mystisk eller metafysisk (skønt han ved en bestemt verdensanskuelse også kan få et sådant udtryk), det er et konstituerende moment ved hele ytringen, som ved en dybere analyse kan opdages i den. Dette udspringer af ordets natur: ordet $\emptyset$ nsker altid at blive hørt, det søger altid responsforståelse og standser ikke ved den mest narliggende forståelse, men bliver ved med at gro (grænseløst).

For ordet (og følgeligt for mennesket) findes der ikke noget mere frygteligt end mangel pá respons. Selv et i forvejen falsk ord er aldrig absolut falsk, og det forudsætter altid en instans, som vil kunne forstå og retfærdiggøre det, selv i formen: 'enhver anden ville også have løjet sådan $i$ mit sted' .

Som Karl Marx sagde: kun den tanke som er udtrykt i ordet, bliver en virkelig tanke for en anden og kun derved også for mig selv. ${ }^{19}$ Men denne anden er ikke kun den nærmeste anden (den anden adressat): i sin søgen efter responsforståelse går ordet stadig videre.

Det at blive hørt er som sådan allerede et dialogisk forhold. Ordet ønsker at blive hørt, forstået, besvaret og påny svare på svaret og således ad infinitum. Det indgår i dialogen, som ikke har nogen meningsmaessig afslutning (men for den ene eller den anden deltager kan den være fysisk afbrudt). Dette svækker selvfølgelig på ingen måde ordets genstandmæssige, forskningsmæssige intentioner, dets koncentration om sin genstand. Begge momenter er to sider af samme sag, de er uløselig forbundet. Et brud mellem dem sker kun i et bevidst falsk ord, dvs. i et sådant ord som ønsker at bedrage (et brud mellem genstandsmæssig intention og den intention at blive hørt og forstået).

Ordet, der frygter den tredje og kun søger midlertidig anerkendelse (responsforståelse af begrænset dybde) hos de nærmeste adressater.

Kriterier for forståelsens $d y b d e$ som et af de højeste kriterier i den humani- 
stiske erkendelse. Ordet, hvis bare det ikke er bevidst løgn, er bundløst. At vokse i dybde (og ikke i højde og bredde). Ordets mikroverden.

Ytringen (taleværket) som uigentageligt, historisk enestående og individuelt hele.

Dette udelukker selvfølgelig ikke en kompositionel-stilistisk typologi for taleværker. Der eksisterer talegenrer (dagligdags, retoriske, videnskabelige, litterære osv.). Talegenrer - det er typemodeller for opbygningen af en taleenhed. Men disse genremodeller adskiller sig principielt fra lingvistiske satningsmodeller.

Sprogets enheder, som bliver studeret af lingvistikken, er principielt reproducerbare et ubegrænset antal gange i et ubegrænset antal ytringer (til det reproducerbare hører også sætningsmodeller). Dog er hyppigheden af reproduktionen forskellig ved forskellige enheder (højest ved fonemer, lavest ved fraser). Kun takket være denne reproducerbarhed kan disse enheder udfylde deres funktioner som sprogenheder. Lige meget hvordan man definerer forholdene mellem disse reproducerbare enheder (opposition, sammenstilling, kontrast, distribution osv.), kan disse forhold aldrig være dialogiske, hvilket ville ødelægge deres lingvistiske (sproglige) funktioner.

Enheder af talesamvær - hele ytringer - er ureproducerbare (selv om de kan citeres) og er forbundet med hinanden ved hjælp af dialogiske forhold.

Oversat fra Estetika slovesnogo tvortjestva, redaktion og tilrettelaggelse $S$. G. Botjarov. Noterne (nedenfor noterne 7-19) er redigeret af oversatterne på grundlag af $S$. S. Averintsev og S.G. Botjarovs noter i ovennavnte russiske udgave.

\section{Noter}

1. Peter Madsen: Semiotik og dialektik, København 1971 og Anker Gemzøe: »Dialogen og den tragiske farce $\mathbf{i}$ Poetik, 4. årgang nr.1, 1971.

2. M.M. Bakhtin: Estetika slovesnogo tvortjestva, Moskva 1979.

3. Vi har valgt at bevare den direkte oversettelse af russisk 'slovo' til dansk »ord «, da vi finder den mest tro mod originalteksten og vores ønske om at være så tæet pă denne som muligt. Det russiske ord 'slovo' kunne også oversættes til diskurs, ytring, vark, tale afhængigt af konteksten, men det kan altid, uden fejltolkninger, oversættes til ord. Det har den samme brede nuancering som den danske brug af ord, som f.eks, i den grundtvigianske forestilling om det levende ord. Vi har fravalgt at kalkere ordet som 'slovo', da det vil give nogle fagsprogskonnotationer, som ordet ikke har pä russisk.

4. M.M. Bakhtin: Problenty poetiki Dostojevskogo, Moskva 1963 (org.1929).

5. M.M. Bakhtin: »The Problem of the Text in Linguistics, Philology and the Human Sciences. An Experiment in Philosophical Analysis in Speech Genres and Other 
Late Essays. A Selection of Bakhtin's Works ed. by Emerson, C. and M. Holquist, Austin, Texas 1986.

6. »Metalingvistik « er af en af de største Bakhtin-oversættere, J.Kristeva, blevet oversat til translingvistik. Vi har valgt at bevare begrebet metalingvistik, vel vidende at det $\mathrm{i}$ dag også bruges i en anden betydning, men denne ligger langt fra den bakhtinske forståelse. Vi finder, at der er for meget fortolkning i translingvistik. Som det vil fremgå af artiklen arbejder Bakhtin også med begrebet ikke-lingvistisk.

7. Ordspil fra L. Tolstojs Anna Karenina:

»- De har kun Dem selv i tankerne - javel! Men hvad andre lider interesserer Dem ikke. Hvad den mand, som har været Deres ægtefælle, har lidt og dsidt ... sidt ... sidt ...

Aleksej Aleksandrovitsj talte så hastigt og så heftigt, at hans tunge slog̣ klik, så han ikke fik ordet stridt rigtigt frem, men sløjfede midten og sagde sidt.« fra E. Thomassens oversættelse, Kbh., 1971, bd. 2, p.110.

8. »Bevidsthed som problem i adfærdspsykologi« behandles i V.N.Volosjinovs: Freudianisme, Moskva 1927, isæer pp.31 f.

9. Fra Johannes Scotus Eriugena: Om opdelingen af naturen. De tre begreber betyder:
a. Den skabte natur $=$ ting.
b. Den fødte og skabende natur = (Spinoza) PIatons ideverden som findes i Guds intellekt, og som bestemmer tingenes tilstedeværelse.
c. Den skabende og ikke skabte natur $=$ Gud som alle tings årsag.

10. $\gg \mathrm{Ja}$, her ser du altså din ømme ægtemage, øm som året efter brylluppet, fortæret af længsel efter at se dig igen - begyndte han med sin sædvanlige læspen og smagende på hvert ord; denne tone, som han næsten altid anvendte over for hende, skulle udtrykke hans spot over de mennesker, der virkelig havde grund til at tale sådan.«, Anna Karenina, op.cit., bd.1, p.132.

11. V.A. Sjukovskij: To sagn og et til. 1831. Det tredje sagn er en genfortælling på vers af en prosafortæling af $\mathrm{J}$. Hebbel: »Kannitverstan «, om en tysk håndværker, som under et ophold i Amsterdam uden at kunne det hollandske sprog, på alle sine spørgsmål fik et og samme svar: »kannitverstan « (jeg kan ikke forstå Dem) og som tog det for et personnavn, hvilket $i$ hans bevidsthed skabte et fantastisk billede af personen Kannitverstan.

12. Bakhtin brugte i sin analyse Jevgenij Onegin som eksempel på dialogstilleje i et værk, som bevidst benytter flere stillejer. Voprosy literatury i estetiki, pp.410-17.

13. R. Hirzel: Der Dialog. Ein literaturhistorischer Versuch, bd. 1-2, Leipzig 1895.

14. M.M.Bakhtin: Tvortjestvo Rable i narodnaja kultura srednevekovja i renessansa (Rabelais' forfatterskab og folkekulturen i middelalderen og renæssancen), Moskva 1965.

15. Sandsynligvis henvises her til bogen: Leo Spitzer: Romanische Literaturstudien 1936-56, Tübingen 1959.

16. Forskellige former for gengivelse af en andens tale (tjusjaja retj) i russiske sprogkonstruktioner: spredt, skjult, tingsliggjort, erstattet og ikke-direkte direkte tale (om hvilket han skrev et stort, separat kapitel) blev detaljeret beskrevet af V. N. Volosjinov allerede i 20 'erne i Marxisme og sprogfilosofi.

17. Fra Pusjkins artikel »Silvio Pellicios værk: Om menneskets forpligtelse«, 1836: »Hjernen er uudtømmelig i udtænkning af begreber, ligesom sproget er uudtømmeligt $\mathbf{i}$ ordkompositioner. Alle ord findes i leksika, men bøger som bliver til hvert minut er i sig selv ikke gentagelse af leksika, A.S.Pusjkin: Samlede varker 1-10, 
Moskva-Leningrad 1964, bd. 7, p.472.

18. T. Mann: Dr. Faustus, kap. XXV, Stockholm 1947, p. 378 f. I samtale med Adrian beskriver Djævelen helvede som en dyb, lydtæt kælder uden for Guds hørevidde. Da Thomas Mann kommenterede dette i sin bog Die Entstehung des Dr. Faustus, skrev han om Djæuelens beskrivelse, at den »er utænkelig, uden at man har den indre erfaring om Gestapokælderen«, op.cit., Frankfurt a.M. 1960, p. 75 (org. 1949).

19. Kildeangivelsen i originalen er uklar. 
